\title{
Semantic Errors in the Translation into English about Actions to Defend Islam in 2016
}

\author{
Danti Pudjiati \\ English Language and Literature Department \\ SyarifHidayatullah State Islamic University of Jakarta, \\ Indonesia \\ danti.pudjiati@uinjkt.ac.id
}

\author{
Elisa M Fadilah \\ English Language and Literature Department \\ SyarifHidayatullah State Islamic University of Jakarta, \\ Indonesia \\ elisam.fadilah13@mhs.uinjkt.ac.id
}

\begin{abstract}
As defending Islam actions in 2016 were the greatest historical moment in Jakarta with a significant impact on Muslims in Indonesia, one of Islamic organizations, HizbutTahrir Indonesia (HTI), recorded these actions through Instagram in Indonesian which can be read as well in English through the newest InstagramMachine Translation (IMT) of 10.3.2 version. These translated captions produced by IMT are interested to be studied because no research has discussed about it yet. Therefore, this study was conducted with two purposes, firstly, to find out semantic errors of referential, grammatical, and contextual meaning of translated captions. Another purpose was to determine whether or not people have advantages to use IMT for understanding the captions in English. The data were HTI's translated captions relating with three defending Islam actions in the late 2016 that were analyzed qualitatively through comparing both captions between the source language and target language in order to describe errors based on semantic aspects theory. The research result showed successively that three kinds of semantic errors, namely grammatical, contextual, and referential meaning were significantly there. All these errors proved that IMT cannot translate the captions accurately from Indonesian into English. In conclusion, IMT is not able to translate successfully and this implies that human translation is more reliable than IMT. Therefore, it is suggested that Instagram creator should evaluate and improve the quality of inn-app text translation feature, for example by applying the service of correctionbutton.
\end{abstract}

Keywords - Semantic errors, Instagrammachine translation, actions to defend Islam

\section{INTRODUCTION}

HTI, as one of the Islamic community organizations in Indonesia, posted its activities in Instagram regarding to actions of defending Islam in Jakarta. The first action was held on Friday, October $14^{\text {th }} 2016$ followed by thousands of people. The second took place in November $4^{\text {th }}, 2016$ attended by around 200.000 people. The agreement between the committee of GNPF MUI and the police dealing with the third action in December $2^{\text {nd }}, 2016$ in National Monument was cleared; the concept of this action was organized differently by establishing a religious event to pray together concluded by Friday prayer in that place. People joined to that action doubled than the previous ones, around 500.000, made this action into the greatest of memorable moment for the Muslims who came there and as well as for local and foreign journalists who wrote the report.

Now adays public are more interested in communicating through visual media such as photos. One of the social media implemented to maximize the communication by photo is Instagram. Because of easiness to use Instagram translation feature as supported by machine, it becomes a favorite social media for most people. As it was rightly proven that machine translation refers to computerized systems responsible for the production of translations with or without human assistance [1].

Someone might upload his photos in Instagram and typed the captions using Indonesian. Soon, these captions in Indonesian could be easilytranslated into English by clicking "See Translation" because Instagram provides in-app text translation feature. This condition develops into a new problem in the field of translation. One of them is the quality of translation accuracy which is very important in order to avoid the misunderstanding of communication in social media. Therefore, this study was conducted with two objectives, namely to find out the translation assessment of semantic errors of the captions posted by HTI in responding with the actions to defend Islam using ITM of version 10.3.2. Secondly, it was to prove whether or not people may depend on this version to translate the captions from Indonesian intoEnglish.

Previous researches relating to machine translation and the assessment were investigated by Felice and Specia in 2013 [2], Avramidis in 2013 [3], and by Giménez and Márquez in 2011 [4]. The difference between Felice and Specia' study and this is the focus of classifying the selected data and the corpus of analysis. They focused on three English- Spanish translation meanwhile we used the Indonesian to English Translation. After that, Avramidis analyzed the translation of quality estimation with ranking sentence-level while this research concentrated in translation errors based on semantic aspects. Then, Giménez and Márquez applied three instruments, namely linguistic, semantic, and syntactic and combined the ways among them, however, we had one instrument, namely semantic. Therefore, this study has a novelty because discussing the quality of translation made by 
the ITM of the newest version with the Indonesian captions which has not been studied yet before.

Briefly, the two objectives of this study are the first, to discover semantic errors of referential, grammatical, and contextual meaning of translated captions of HTI's accountposted in Instagram. The second objective is to clarify whether or not there are some advantages for people to use IMT for understanding the captions in English from Indonesian. In addition, the thesis statement of this research is people are possible to use IMT when they would like to understand the captions from Indonesian intoEnglish.

\section{THE QUALITY OF TRANSLATION}

Discussing a good translation, certainly, relates closely with quality. House explained that the judgment of translation quality depends on a large variety of factors entering into any social evaluative statement [5]. Furthermore, Barnwell also claimed that the three most important qualities needed in good translation are(1) accuracy; correct exegesis of the source message and transfer of the meaning of it as exactly as possible into receptor language, (2) clarity; there may be several different ways of expressing anidea,choose the way to communicate as clearly as possible; the way which ordinary people will understand, (3) naturalness; it is important to use the natural form of the receptor language in order that the translation will be effective and acceptable[6].

A translation should not sound unnatural. Likewise, Barnwell and Nababan[7] shared the same idea about the quality of translation, in terms of three points, namely the accuracy in transferring message, the clarity of expressing the message in target language, and the naturalness of translation language. Therefore, we concluded that a translator should consider accuracy, clarity, and naturalness so that the result of translation could be accepted by the readers.

\section{TRANSLATION ASSESSMENT MODEL}

Assess a translation is difficult because it must be objective to find out the quality of translation. The translation assessment model by Sayogie was used, divided into seven aspects, namely linguistics (transposition, modulation, and adaptation), semantics (grammatical meaning, contextual meaning, and referential meaning), pragmatics (writer's goal of source language agreement, textual meaning agreement), the level of naturalness, particular terminology, spelling use, and the textual level[8].

This research applied semantic aspect of three parts, namely referential meaning, contextual meaning, and grammatical meaning. According to Kridalaksana "Grammatical meaning is the relationship between the language elements in the larger unit such as the relationship of a word with another word in the phrase or clause" [9]. Furthermore, Nababan gave examples such as the word "can" means dapat, or mengalengkan, depending on the position of the word in a sentence. The word "can" in a sentence, "they can fish," serves as the predicate in the form of the verb, whereas the word "can" in a sentence, "He kicked the can hard," as the object of the sentence[7].

Kridalaksana stated that contextual meaning is the relationship between utterance and situation where that the utterance was used. On the other hand, Nababan claimed it is the meaning of a word which is associated with language situations. Referential meaning according to Larson was something that is referenced or referenced directly which may take the form of objects, events, attribute, or particular relation thatcanbeseenorimaginedbywordsorsentences[10].

\section{METHOD}

The data were the captions of the SL and TL relating to defending Islam action one, two, and three obtained from hizbut-tahrir.or.id (see in the appendices) or on HTI's Instagram account namely hizbuttahririd. The

TL captions were the result of Instagram machine translation version 10.3.2 analyzed by applying qualitative descriptive method. This method aims to collect information in order to find the conclusion with verbal description as stated by Farkhan [11].

The data were treated by comparing the translation to the SL, analyzing the translation errors through consulting with semantic aspects, and elaborating between theory of translation assessment and deciding kinds of translation errors of referential, grammatical, and contextual meaning. The instrument of the research was the writers themselves to support the research design, namely qualitative research. The data presented show the translation errors selected randomly from the captions.

\section{TABLE 1}

The Captions Between Sl And Tl Of Action One

\begin{tabular}{|c|c|c|c|c|c|}
\hline \multirow[t]{2}{*}{ No } & \multirow[t]{2}{*}{ Source Language } & \multirow[t]{2}{*}{$\begin{array}{c}\text { Target } \\
\text { Language }\end{array}$} & \multicolumn{3}{|c|}{$\begin{array}{l}\text { Translation Errors } \\
\text { of Semantic Aspect }\end{array}$} \\
\hline & & & RM & GM & $\mathrm{CM}$ \\
\hline 1. & Tiga sikap & three attitude & & Y & \\
\hline 2. & $\begin{array}{l}\text { KPU DKI } \\
\text { Jakarta Diminta }\end{array}$ & $\begin{array}{l}\text { Kpu, dki } \\
\text { Jakarta, Asked } \\
\text { Asked }\end{array}$ & & Y & \\
\hline 3. & $\begin{array}{l}\text { Dia menyebut } \\
\text { apa yang ada } \\
\text { dalam Al- } \\
\end{array}$ & $\begin{array}{l}\text { he mentioned, } \\
\text { what is in the } \\
\text { Qur'an absolute }\end{array}$ & $\mathrm{Y}$ & Y & \\
\hline 4. & $\begin{array}{l}\text { Al-Qur'an } \\
\text { adalah acuan } \\
\text { kehidupan } \\
\text { umat Muslim }\end{array}$ & $\begin{array}{l}\text { Qur'an is in the } \\
\text { life of the } \\
\text { Muslim } \\
\text { Ummah }\end{array}$ & & Y & \\
\hline
\end{tabular}


Table 1, cont.

\begin{tabular}{|c|c|c|c|c|c|}
\hline 4. & $\begin{array}{l}\text { Al- } \\
\text { Qur'anadala } \\
\text { h acuan } \\
\text { kehidupan } \\
\text { umat Muslim }\end{array}$ & $\begin{array}{l}\text { Qur'an is in the } \\
\text { life of the } \\
\text { Muslim } \\
\text { Ummah }\end{array}$ & & Y & \\
\hline 5. & $\begin{array}{l}\text { ICMI menilai } \\
\text { perbuatan } \\
\text { Ahok jelas- } \\
\text { jelas tercela }\end{array}$ & $\begin{array}{l}\text { Icmi assesswhat } \\
\text { ahok are clearly } \\
\text { toblamey }\end{array}$ & & Y & $\mathrm{Y}$ \\
\hline 6. & Menegaskan & Has & & & $\mathrm{Y}$ \\
\hline 7. & $\begin{array}{l}\text { Pernyataan yang } \\
\text { dengan terang } \\
\text { dan Jelas }\end{array}$ & $\begin{array}{l}\text { with the light of } \\
\text { the statement } \\
\text { and clearly }\end{array}$ & & $\mathrm{Y}$ & $\mathrm{Y}$ \\
\hline 8. & $\begin{array}{l}\text { Perundang- } \\
\text { undangan }\end{array}$ & law-invites & & & Y \\
\hline 9. & Kitab suci & Book & & & \\
\hline 10 & $\begin{array}{l}\text { Iman umat } \\
\text { Muslim tak } \\
\text { akan menolak } \\
\text { isi }\end{array}$ & $\begin{array}{l}\text { muslim's faith } \\
\text { won't resist the } \\
\text { contents of the } \\
\text { child. }\end{array}$ & Y & & $\mathrm{Y}$ \\
\hline
\end{tabular}

Note: RM (Referential Meaning), GM (Gramatical Meaning), CM (Contextual Meaning), Y (Yes)

TABLE 2

The CAPTIONS BeTweEn SL AND TL Of ACTION Two

\begin{tabular}{|l|l|l|c|c|c|}
\hline No & Source Language & Target Language & \multicolumn{3}{|c|}{$\begin{array}{l}\text { Translation Errors } \\
\text { of Semantic Aspect }\end{array}$} \\
\cline { 3 - 6 } & & RM & GM & CM \\
\hline 1. & $\begin{array}{l}\text { Massa } \\
\text { bergerakdari }\end{array}$ & $\begin{array}{l}\text { Mass move of } \\
\text { istiqlal mosque }\end{array}$ & & $\mathrm{Y}$ & \\
\hline 2. & $\begin{array}{l}\text { Mobil } \\
\text { polisimulaimerang } \\
\text { sekkepeserta }\end{array}$ & $\begin{array}{l}\text { police car start } \\
\text { push to } \\
\text { participants }\end{array}$ & & $\mathrm{Y}$ & \\
\hline 3. & $\begin{array}{l}\text { Pesertabertahande } \\
\text { ngancara duduk }\end{array}$ & $\begin{array}{l}\text { Participants } \\
\text { survive } \\
\text { by sat }\end{array}$ & & $\mathrm{Y}$ & \\
\hline
\end{tabular}

TABLE 3

The Captions Between Sl And Tl Of Action Three

\begin{tabular}{|l|l|l|l|l|l|}
\hline No & \multirow{2}{*}{$\begin{array}{c}\text { Source } \\
\text { Language }\end{array}$} & Target Language & \multicolumn{3}{|c|}{$\begin{array}{c}\text { Translation } \\
\text { Errors of } \\
\text { Semantic Aspect }\end{array}$} \\
\cline { 4 - 6 } & & & RM & GM & CM \\
\hline 1. & Anarkis & SYMBOLISM & & & Y \\
\hline 2. & Kehinaan & Honour & & & Y \\
\hline 3. & Syari'ah & Banks & & & Y \\
\hline 4. & Monas & $\begin{array}{l}\text { EARTH } \\
\text { RADIO }\end{array}$ & & Y & Y \\
\hline
\end{tabular}

\section{RESUlt AND DisCUSSION}

The result of data analysis showed that IMT produced some translation errors. Details are explained as follows.

\section{A. Defending Islam ActionOne}

Datum one and two contain translation error in grammatical meaning for written in the plural form in SL (tigasikap) but translated into singular (three attitude). SL of datum two is written in the passive form but in TL, it becomes active form producing different meaning. Datum three has translation error in referential meaning. It can be seen from SL "dia menyebutapa yang ada dalam Al- Qur'an mutlak kebenaran." In SL diais a reference of "Sri AstutiBuchori." She is a vice of public chairman of ICMI, translated into "he" not "she." Besides, TL has an error in grammatical meaning. "He mentioned" as $\mathrm{S}+\mathrm{V}$, while "what is in the Qur'an absolute truth" is the noun clause used as an object of verb "mentioned." There was no auxiliary verb "is" after "al-Qur'an".

Datum four, five, and six have incorrect translation in grammatical meaning. Datum four reveals misunderstanding of the meaning of acuanin SL, translated into life in TL. In fact, it should be the guidance. And, the word of ummah should be deleted as well since there was a redundancy. It should be written in simple past in TL of datum five because that event occured in the past in SL. Datum six has errors of verb (are) and incorrect translation of adjective (tercela). It is better to translate "is" not "are" because the noun (perbuatan) is singular in TL. F u r the r m o re, tercelawas written in adjective in SL, howeverin TL it was translated into verb. Furthermore, there was also a missing noun (perbuatan). In addition, it produced translation error of "ICMI" writing in T L i n to capital letters because it is an acronym of "Ikatan Cendikiawan Muslim Indonesia", a name of organization in Indonesia. In the sense of contextual meaning, it had a translation error, tercelais translated into "blame" which is not appropriate with the context of SL.

Datum six has translation error in contextual meaning. The reason is "menegaskan" translated into "has" in TL. Certainly, it did not fulfill the meaning of SL. Here, menegaskanmeans 
clarify or giving clarification. Therefore, in this context, menegaskanmeans "clarify" or "strengthen" by providing facts or proofs. In the term of grammatical meaning, datum seven is classified as incorrect translation. In SL "denganterangdanjelas" functioned as adverb of noun (pernyataan), but in TL becomes an adverb "clearly." Moreover, in SL "terang" acts as "adjective," however it is "light" as "noun" in TL.

Datum eight contains translation error of contextual meaning. In SL "perundang-undangan" relates to law terminology which can be seenobviously in SL "pernyataan yang dengan terang dan jelas menunjukkan bahwa pejabat negara tersebut telah melakukan pelanggaran terhadap beberapa peraturan perundang- undangan di Indonesia." It should be translated into "legislation." Datum nine is proved to have translation error of contextual meaning. In this context, kitabsucimeans the holy book of Moslem. It refers to al-Qur'an as holy book for Moslem. Therefore, to fulfill the meaning of SL, it issuggested "holy book." Last datum has translation error of referential meaning. Actually, "nya" in SL refers to the holy book (al-Qur'an), but IMT was not able to recognize it. It can be seen noticeably in SL that "kandungannya" means "content of al-Qur'an," but in TL it was written "the content of the child" showing different meaning.

\section{B. Defending Islam Action Two}

All of three data here have translation error of grammatical meaning. Datum one is about preposition as seen in SL, preposition "dari" is translated into "of." The correct preposition is "from" not "of." It is because in this context, that sentence shows a movement by people from a place to another place. There are two verbs, "start and push" in TL of datum two. It should be ad d ed "to" before the word push. The reason is both "start" and "push" are functioned as verb. The translation of datum three, in the view of grammatical rule showed an error. The following word after "by" must be in gerund. Therefore, the translation should be participants survive by sitting down.

\section{Defending Islam Action Three}

In term of contextual meaning, datum one, two, three, and four undoubtedly contains translation error. If "anarkis" is translated as "symbolism," it cannot fulfill the meaning of SL. According to KBBI, Indonesian dictionary, "anarkis" means the follower of anarchy and anarkist. The full sentence is AksiUmat Islam anarkis. "Anarchist" is someone who believes that there should be no government or laws. In addition, "symbolism" is the use of symbols to express or representideasorqualitiesinliteratureorart,namelythe particular idea or quality that is expressed by asymbol.

The full sentence of SL of datum two, is ketiga hal itu seharusnya menjadikan optimis memuncul dalam diri umat Islam untuk bangkit dari keterpurukan dan kehinaan menuju kejayaan. The IMT translated "kehinaan" as "honour," definitely, is inappropriate with SL "kehinaan." Kehinaan is a noun, meaning a despicable character. Meanwhile, "honour" means penghargaan, not kehinaan. Shortly, kehinaanis suggested to tranlate intohumiliation.

In datum three of SL syariah relates to the context of Islamic law, stated in full sentence "dengan tegaknya Syariah \& Khilafah." In Indonesia, the meaning of Syariah based on $\mathrm{KBBI}$ is the religion law which set the human regulation between man and God, menand men, and men and their surrounding based on Koran and Hadist. However, "banks" is a mound, pile, or ridge raised above the surrounding level, the rising ground bordering a lake, river, or sea or forming the edge of a cut or hollow. Therefore, the translation isclaimed to be incorrect since it is not intended message.

Datum four shows that "Monas" is translated into "Earth Radio" which does not meet the meaning of SL. As a consequence, it had translation error of contextual meaning. Essentially, Monas is a short form of Monumen Nasional, a historical monument. In this context, Monas is place where Moslem did the third action to defend Islam in the second of December in Jakarta.

\section{CONCLUSION}

From seventeen data analyzed, there were ten errors of grammatical meaning, nine errors of contextual meaning, and two errors of referential meaning. This leads to a decision that IMT of 10.3.2 version is not able to translate well the posting of HTI's Instagram account for responding the first, second, and third of defending Islam action in 2016. Therefore, people are encouraged not to rely on this IMT to translate the captions from Indonesian into English. It implied as well that human as a translator still play an important role to produce a goodtranslation.

We recommend to Instagram creator to evaluate and improve the quality of in- app text translation feature, for example by applying the "correction" button. The administrator of HTI's account should write their postings i n English with serious attention to grammatical and contextual meaning be forepostingif they have intention that their postings will be understood by foreigners. Another suggestion is also addressed to the people with Instagram application, particularly for using Instagram's in-app text translationfeature.

\section{REFERENCE}

[1] J. Hutchins. Machine translation: general overview. chapter 27: 502505. Pdf.

[2] Felice, M and Specia, L. (2013). Investigating the contribution of linguistic information to quality estimation." Springer 27.3: 2- 19. Pdf.

[3] Avramidis, E. (2013). Sentence-level ranking $w$ ith quality estimation. MT Journal Manuskrip. Springer 27.3/4: 2-16. Pdf.

[4] Giménez, J. and Márquez, L. (2011). Linguistic easures for Automatic Machine Translation Evaluation. Springer 24. 3/4 : 2-24.Pdf.

[5] House, J. Translation quality assessment: linguistic description versus social evaluation. Hamburg: University of Hamburg, p. 254. 2001.

[6] Barnwell, K. Introduction to semantic and translation. England: Summer Institute of Linguistics, p. 15. 1980.

[7] Nababan, R..Teori Menerjemah Bahasa Inggris. Yogyakarta: Pustaka. Pelajar, p. 49 and 86. 2008.

[8] Sayogie, F. Teori dan Praktik Penerjemahan. Tangerang Selatan: 
Transpustaka, p. 145,165. 2014.

[9] Kridalaksana, H. Kamus Linguistik Edisi Keempat. Jakarta: Gramedia, p.120. 2008.

[10] Larson, M. Meaning-based translation: a guide to cross-language equivalance. Lanham: University Press of America, p. 26. 1984.

[11] Farkhan, M. Proposal Penelitian Bahasa dan Sastra. Jakarta: Adabia Press. 2011. 